\title{
Effect of Starvation and Refeeding on the Circadian Rhythms of Hematological and Clinico-biochemical Values, and Water Intake of Rats
}

\author{
Kazuhito MAEJIMA and Sumi NAGASE* \\ Japan Automobile Research Institute, 2530 Karima, Tsukuba-shi, Ibaraki 305, and \\ *Sasaki Institute, 2-2 Surugadai, Kanda, Chiyoda-ku, Tokyo 101, Japan
}

(Received 19 October 1990/Accepted 13 February 1991)

\begin{abstract}
We investigated the effect of starvation for $24 \mathrm{hr}$ and subsequent refeeding for $12 \mathrm{hr}$ on the circadian rhythms of 39 hematological and clinico-biochemical parameters, and water intake of F344 rats. The rats scarcely drank any water during the starvation period, but subsequently their intake of water were normal, even in the light period. During starvation, 12 parameters such as serum levels of alkaline phosphatase activity and $\mathrm{PaCO}_{2}$ decreased with time-related and time-related increases of 8 parameters such as the erythrocyte count and cholinesterase activity. During refeeding for $12 \mathrm{hr}$, almost all these biochemical parameters were normalized, but none of the hematological values except the leukocyte count returned to normal levels. Starvation and refeeding had little affect on the circadian rhythms of others.

- KEY WORDS : blood, circadian rhythm, starvation, water intake
\end{abstract}

We previously reported various changes in hematological and clinico-biochemical values and also dose-dependent decrease in body weight, and food and water intakes of F344 rats exposed to diesel exhaust [5]. The circadian rhythm of water intake in the rats also changed [6]. Therefore, we wondered whether decrease and/or change in circadian rhythms of food and water intakes affected the hematological and clinico-biochemical values of the rats. So we examined the effects of starvation and refeeding on the circadian rhythms of hematological and clinico-biochemical parameters, and water intake of rats.

Male F344/Jcl rats (SPF) of 10 weeks old, were obtained from CLEA Japan Inc. During the experiment, groups of rats with same mean body weight were housed five to a plastic cage $(265 \times 425 \times 200 \mathrm{~mm})$ with wood shavings in an air-conditioned room (temperature : $24 \pm 2{ }^{\circ} \mathrm{C}$, relative humidity : $55 \pm 10 \%$ ), with artificial lighting $12 \mathrm{hr}$ a day from $7 \mathrm{AM}$ to $7 \mathrm{PM}$. They were acclimatized to these conditions for a week. Then they were either fed a normal standard diet (CE-2, CLEA Japan Inc.) ad libitum or starved for $24 \mathrm{hr}$, and refed on normal standard diet for $12 \mathrm{hr}$, unless otherwise indicated. All rats were given tap water ad libitum.

The body weights, and food and water intakes of fed and starved groups were measured every $6 \mathrm{hr}$ from the start of the experiment, and blood was drawn into a heparinized syringe from the abdominal aorta of five rats at each time under ether anesthesia. Part of the sample was used for measuring blood gases, and the rest was centrifuged to separate the plasma. Blood containing EDTA-2 $\mathrm{K}$ was stored in a capillary whole blood collector for hematological analysis. The rest of the blood was centrifuged to separate the serum. The parameters measured were: the activities of glutamic oxalacetic transaminase (GOT), glutamic pyruvic transaminase (GPT), lactate dehydrogenase, creatine phosphokinase, alkaline phosphatase and cholinesterase, and blood urea nitrogen, creatinine, total bilirubin, glucose, 
triglyceride, total cholesterol, free cholesterol, low density lipoprotein, high density liporotein, phospholipid, calcium, magnesium, inorganic phosphorus, sodium, potassium, chlorine, total protein, albumin, $\alpha_{1}$-globulin, $\alpha_{2}-$ globulfn, $\alpha_{3}$-globulin, $\beta$-globulin, and $\gamma$-globulin, the erythrocyte count, leukocyte count, platelet count, hematocrit, hemoglobin concentration, arterial blood $\mathrm{pH}(\mathrm{pHa})$, carbon dioxide partial pressure $\left(\mathrm{PaCO}_{2}\right)$, oxygen partial pressure $\left(\mathrm{PaO}_{2}\right)$, bicarbonate, and the anion gap. The anion gap was calculated as : (sodium + potassium $)$ - (chlorine + bicarbonate). Further, details of measurements are given elsewhere [7] .

The mean body weight of starved rats decreased with time and was $91 \%$ of the initial body weight after $24 \mathrm{hr}$. Even after refeeding for $12 \mathrm{hr}$, the mean body weight was not restored to that initially. The mean food intakes of fed rats from $9 \mathrm{AM}$ to $3 \mathrm{PM}, 3 \mathrm{PM}$ to $9 \mathrm{PM}, 9 \mathrm{PM}$ to $3 \mathrm{AM}$, and $3 \mathrm{AM}$ to $9 \mathrm{AM}$, were $0.8,3.6,4.6$, and $4.2 \mathrm{~g} / \mathrm{rat}$, respectively. The mean food intakes of refed rats from $9 \mathrm{AM}$ to $3 \mathrm{PM}$ and $3 \mathrm{PM}$ to $9 \mathrm{PM}$ were 4.3 and $6.8 \mathrm{~g} / \mathrm{rat}$ each. Fig. 1 shows the changes of mean water intakes of the fed, starved, and refed rats. The values showed a similar trend to those for mean food intakes.

A circadian rhy thmic change was observed in the leukocyte count of the fed rats : the level was high (appoximately 5,000 cells/ $\mu l$ ) in the light period and decreased in the dark period. Starvation and refeeding did not seem to influence this circadian rhythm. There was no detectable difference in the erythrocyte counts of fed rats and those starved for $12 \mathrm{hr}$, but after starvation for $24 \mathrm{hr}$, the erythrocyte count increased $9 \%$ and even after refeeding for $12 \mathrm{hr}$, this increased level was maintained (Fig. 2). Similar tendencies of change were observed in the hematocrit, hemoglobin concentration, and platelet count of starved and refed rats.

Change in alkaline phosphatase activity showed a similar trend to that in body weight in the fed and starved rats; that is, it decreased with time in starved rats, and increased within $6 \mathrm{hr}$ on refeeding. Fig. 3 shows the changes of creatine phosphokinase activity in fed, starved, and refed rats. The activity of the fed rats showed a characteristic circadian rhythm, with a maximum at $3 \mathrm{PM}$ and minimum at $3 \mathrm{AM}$. Starvation for $24 \mathrm{hr}$ and subsequent refeeding for $12 \mathrm{hr}$ scarcely affected the

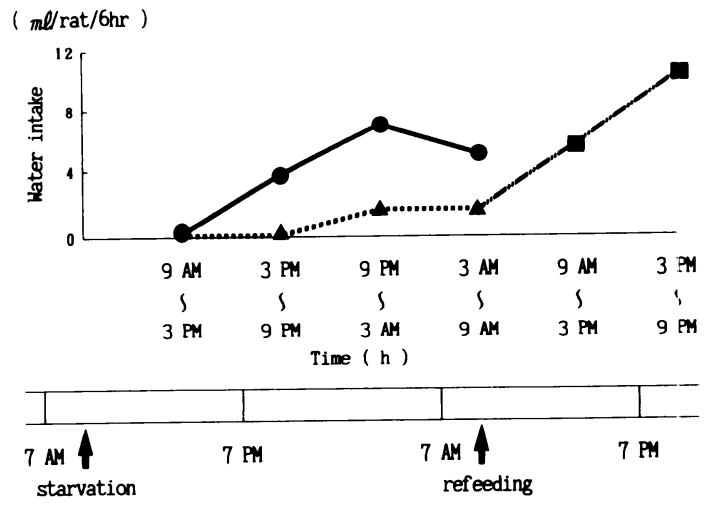

Fig. 1. Mean water intakes in $6 \mathrm{hr}$ periods from the start of the experiment in fed, starved, and refed rats. Values are means for groups of 5 rats. - : fed rats $\boldsymbol{\Delta} \cdots \boldsymbol{\Delta}$ : starved rats and $\square \cdots \square$ : refed rats $\square$ : light period : dark period

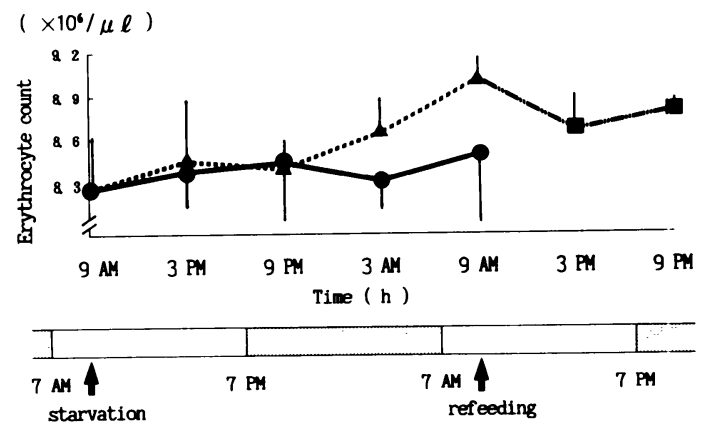

Fig. 2. Erythrocyte counts measured every $6 \mathrm{hr}$ from the start of the experiment in the fed, starved, and refed rats. Values are means \pm S. D. for groups of 5 rats. - fed rats $\boldsymbol{\Delta} \cdots \boldsymbol{\Delta}$ : starved rats and $\mathbf{\square} \cdot \mathbf{\square}:$ refed rats : light period, $:$ : dark period

circadian rhythm of creatine phosphokinase activity.

No remarkable fluctuation except for a minimal at $3 \mathrm{PM}$ was seen in blood urea nitrogen of the fed rats. Starvation for $24 \mathrm{hr}$ scarcely influenced the circadian rhythm of blood urea nitrogen. But, no decrease of blood 


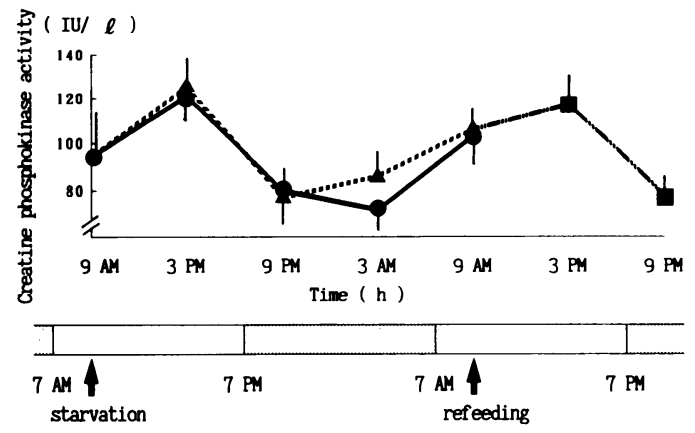

Fig. 3. Creatine phosphokinase activity measured every $6 \mathrm{hr}$ from the start of the experiment in fed, starved, and refed rats. Symbols are as for Fig. 2 .

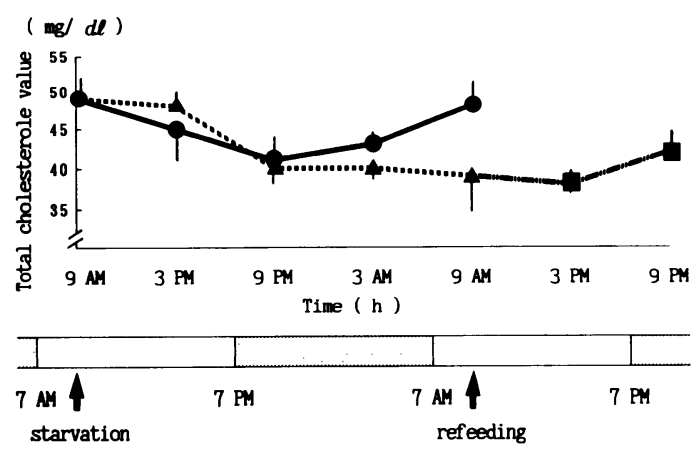

Fig. 4. Total cholesterol measured every $6 \mathrm{hr}$ from the start of the experiment in fed, starved, and refed rats. Symbols are as for Fig. 2.

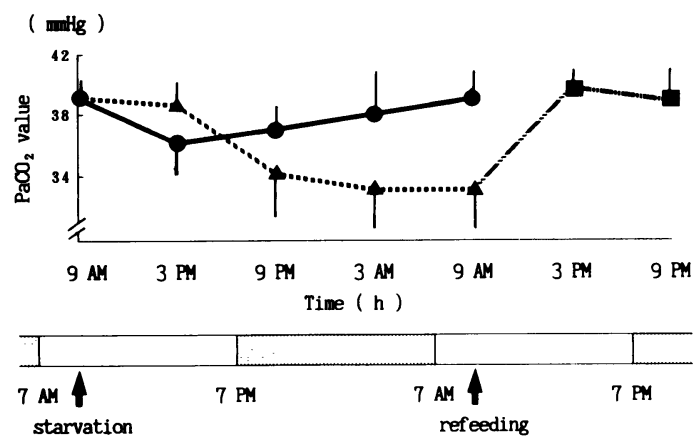

Fig. 5. $\mathrm{PaCo}_{2}$ values measured every $6 \mathrm{hr}$ from the start of the experiment in fed, starved, and refed rats. Symbols are as for Fig. 2. urea nitrogen at $3 \mathrm{PM}$ was seen in rats after refeeding for $6 \mathrm{hr}$. Changes in the patterns of total bilirubin and glucose of fed and starved rats were similar, showing time-related decreases and restoration to the normal levels on refeeding, like alkaline phosphatase activity. Fig. 4 shows the changes of total cholesterol in fed, starved, and refed rats. Time-related decreases from $9 \mathrm{AM}$ to $9 \mathrm{PM}$ and increases from 9 PM to 9 AM were seen. Similar changes were seen in triglyceride, free cholesterol, phospholipid, and low density lipoprotein of fed rats. In starved rats, time-related decreases from $9 \mathrm{AM}$ to $9 \mathrm{PM}$ were also observed, but then the values remained at minimal levels, and were restored to normal levels on refeeding for $12 \mathrm{hr}$. A decrease of total protein was observed after starvation for $24 \mathrm{hr}$ and this was normalized by refeeding. No remarkable differences were recognized between fed and starved rats in the values of other serum parameters.

Fig. 5 shows the changes of $\mathrm{PaCO}_{2}$ values in fed, starved, and refed rats. During starvation, the $\mathrm{PaCO}_{2}$ value began to decrease after $12 \mathrm{hr}$, and then remained low. On refeeding, it returned to the normal level. Similar changes were seen in blood bicarbonate. Increases of sodium and chlorine, and the anion gap and decrease of potassium were observed during starvation for $24 \mathrm{hr}$, and normal levels were restored on refeeding for 6 or $12 \mathrm{hr}$. No remarkable changes were seen in the $\mathrm{pHa}$ and $\mathrm{PaO}_{2}$ values during the experiment.

There are many reports on the effects of food restriction, starvation, and refeeding on the levels of various factors in the blood [1-3, $7-9,11]$, but few on the effects of starvation and refeeding on the circadian rhythms of these factors. In this study, we found the starved rats drank scarcely any water. Therefore, their increases in hemoglobin concentration, hematocrit, and erythrocyte and platelet counts during starvation may reflect hemoconcentration caused by greatly reduced water intake. These results are consistent with the report of Pickering et al. [10]. But, the circadian rhythm of the leukocyte count did not seem to be influenced by starvation and refeeding. The creatine phosphokinase activity of fed rats showed a circadian rhythm that may be related to the behavioral pattern. This findings indicates that a fixed sampling time must be used in inhalation experiments in rats in which creatine 
phosphokinase activity is measured. The decrease in alkaline phosphatase activity observed in starved rats is known to be related to decreased food intake $[10,14]$. Edwards et al. [3] . reported that the minimal rate of hepatic cholesterol biosynthesis at noon (the middle of the light period) and its maximum at midnight (the middle of the dark period) are related to the feeding pattern. On moderate reduction in food intake due to the effects of inhaled materials, a slight elevation of the cholesterol level will be observed as the result of shift in time of maximum biosynthesis. However, after starvation for $24 \mathrm{hr}$, we found that cholesterol did not return to the normal level promptly on refeeding. Thompson et al. [14] reported that starvation for three days caused a significant increase in the anion gap with significant decreases in plasma bicarbonate and whole blood $\mathrm{pH}$, and that these parameters were normalized during refeeding for five days. They concluded that the significant increase in the anion gap was dus to metabolic acidosis. In this study, we observed decreases of $\mathrm{PaCO}_{2}$ and bicarbonate, and slight increase of the anion gap after starvation for $24 \mathrm{hr}$, but no change of $\mathrm{pHa}$. This discrepancy between our results and Thompson's findings on $\mathrm{pHa}$ may be due to the difference in the period of starvation.

These results suggest that if the food intake of rats is restricted by inhaled materials in an inhalation experiment, especially those in which rats are exposed to test materials in the dark period, many parameters of blood composition may be affected by change in the feeding pattern. In fact, some of these changes caused by reduced food intake and/or change in the feeding pattern of rats have also been observed in long-term inhalation experiments to determine the health effects of diesel exhaust $[5,13]$. However, our results do not show whether repeated starvation and refeeding for a long period of two years or more would affect hematological and clinico-biochemical parameters.

In general, conditions in chronic inhalation test is designed to simulate conditions of human exposue. Rats are usually exposed to air pollutants during the dark period when their activity is high and they eat most food, and in many inhalation studies, an intermittent exposure schedule is used $[2,11-12,15]$. The present results should be useful for evaluating results observed in chronic inhalation experiments whether they are caused by the toxicities of inhaled air pollutants or by reduced food intake and/or change in the feeding pattern.

\section{References}

[1] Apostolou, A., Saidt, L., and Brown, W. R. (1976). Lab. Anim Sci, 26, 959-960.

[2] Brightwell, J., Fouillet, X., Cassano-Zoppi, A.--L. Gatz, and Duchosal, F. (1986). Carcinogenic and Mutagenic Effects of Diesel Engine Exhaust, pp 471-485, Ishinishi, N., Koizumi, A., McClellan, R. O. and Strber, W. (eds.), Elsevier, Amsterdam.

[3] Edwards, P. A., Muroya, H., and Gould, R. G. (1972). J. Lipid Res, 13, 396-401.

[4] Esber, H. J., Kuo, E., and Bogden, A. E. (1976). Lab. Anim Sci, 26, 186-189.

[5] Maejima, K. and Nagase, S. (1989). Man and his Ecosystem, 2. pp 149-154, Brasser, L. J. and Mulder, W. C. (eds.), Elsevier, Amsterdam.

[6] Maejima, K. and Takahashi, H. (1990). Exp. Anim, 39, 81-88 (in Japanese with English summary).

[7] Maejima, K. and Nagase, S. (1990). Exp. Anim, 39, 213-222 (in Japanese with English summary).

[8] Numazawa, A. and Osanai, M. (1986). Exp. Anim, 35, 307-314.

[9] Ogawa, Y., Matumoto, K., Kamata, E., Ikeda, Y., and Kaneko, T. (1985). Exp. Anim, 34, 407-416.

[10] Pickering, R. G. and Pickering, C. E. (1984). Toxicol Lett., 21, 271-277.

[11] Schreck, R. M., Soderholm, S. C., Chan, T. L., Smiler, K. L. and D'Arcy, J, B, (1981). J. Appl Toxicol, 1, 67-76.

[12] Stชber, W. (1986). Carcinogenic and Mutagenic Effects of Diesel Engine Exhaust, pp 421-439, Ishinishi, N., Koizumi, A., McClellan, R. O. and Stober, W. (eds), Elsevier, Amsterdam.

[13] Suzuki, T., Nakajima, T., Maejima, K., Kato, A., Takaki. Y., Kuwabara, N., Hisanaga, A., and Ishinishi, N. (1990). J. Japan Soc. Air Pollut., 25, 192-205 (in Japanese with English summary).

[14] Thompson, C. S., Mikhailidis, D. P., Gill, D. S., Jererny, J. Y., Bell, J. L., and Dandona, P. (1989), Lab. Anim Sci, 23, 53-58.

[15] White, H. J., Vostal, J. J., Kaplan, H. J., and MacKenzie, W. F. (1983). J. Appl Toxicol, 3, 332. 
ラットの血液学的・臨床生化学的検査値执よび飲水の サーカディアンリズムに与える絶食と再給食の影響

前島一七・長瀬すみ*

財団法人日本自動車研究所第一研究部

*財団法人佐々木研究所化学部

ラットに24時間の絶食とそれに続く12時間の再給食を 行い, 39項目の血液学的 - 臨床生化学的測定値と飲水の サーカディアンリズムにおよぼす影響を調べた。その結 果, ラットは絶食期間中ほとんど水を摄取しなかった が，その後の再給食では, 明期にもかかわらず水を急激 に摂取した。絶食期間中, アルカリ性ホスファターゼ活
性，炭酸ガス分圧など12項目に経時的な减少が，また， コリンェステラーゼ活性, 赤血球など 8 項目に経時的な 増加が観察された。これらの項目の多くは，12時間の再 給食により正常範囲に回復したが，白血球を除く血液学 的項目は回復しなかった。その他の項目には，ほとんど 影響が認められなかっだ。 